\title{
Analysis of the Performance of Ludrukan Nom-noman Tjap Arek Soeroboio (LUNTAS) in the Legend of Sawung Kampret
}

\author{
Syina Dalila ${ }^{1, *}$ Arif Hidajad ${ }^{1}$
}

\author{
${ }^{1}$ Universitas Negeri Surabaya \\ *Corresponding author. Email:_syina.18012@mhs.unesa.ac.id
}

\begin{abstract}
LUNTAS (Ludrukan Nom-Noman Tjap Arek Soerrobojo) is one of the groups that preserves ludruk by performing Ludrukan in order to be accepted by the community, especially millennials in Surabaya. The authors are interested in reviewing LUNTAS because of the uniqueness that stands out in LUNTAS compared to other Ludruk, namely the form of performance that is not stuck with the structure in general. This study uses a qualitative descriptive method with data collection techniques used are document studies in the form of video performances, literature studies related to the theme of the study, and online interviews. The researcher reviews in detail the existing facts with data obtained from the LUNTAS coordinator. This paper examines how the form of LUNTAS performance in the play Legenda Sawung Kampret, and how LUNTAS with its performance is viewed from the point of view of the players and the audience of the show. The results of this study indicate that the form of LUNTAS performances is not tied to the structure of ludruk performances in general, because LUNTAS seeks to adapt to the community environment by maximizing the capabilities of existing human resources. In addition, LUNTAS can be well received by all levels of society.
\end{abstract}

Keywords: Ludruk, Performance form, LUNTAS

\section{INTRODUCTION}

Ludruk is a traditional art originating from East Java. Ludruk contains the values of the life of the people who support it. Overall, the existence of ludruk has given its role in the life of art and culture in Indonesia, especially in East Java. "Ludruk-an is a traditional performing art which is one of the stages in the learning and regeneration process of a Ludruk group in the current era. The elements of the show are not as complete as Ludruk but it does not take away the essence of Ludruk." [1].

The structure of performances in ludruk since the beginning of independence until now has not changed. Basically the structure of ludruk performances is always followed from generation to generation in a traditional way. The opening begins with the Remo Dance which is a typical dance of East Java, after that it is continued by Bedhayan, which is the attraction of the artists dancing while singing. The next scene is a slapstick which is one of the episodes of the show's structure that brings a humorous scene. The last is the presentation of the play or story [2]. However, what if the form in the show does not meet the ludruk structure?
This research focuses on the form of the LUNTAS (Ludrukan Nom-Noman Tjap Arek Soeroboio) performance in the play Legend of Sawung Kampret, how the form of the LUNTAS performance and the uniqueness and function of LUNTAS for the community. Some of the things that were done to obtain data were document studies in the form of videos, literacy studies in accordance with the theme of the study, and also interviews with the LUNTAS coordinator.

LUNTAS is one of the groups that preserve youth ludruk from Surabaya. He is only 5 years old (established since 2016). One of the uniqueness of LUNTAS is th concept of LUNTAS which is closer to the millennial generation, as well as the LUNTAS story which is more directed towards comedy with a combination of opera comedy, Japanese comedy, and so on that has not been found in other ludruk. LUNTAS has fifteen active members from various backgrounds, workers, students, students, the general public.

Of all the existing Ludruk teams, LUNTAS is considered to have the most potential to introduce the art of ludruk in the most interesting way for Surabaya youth. 
Because LUNTAS introduces ludruk art with comedy that contains moral messages in it. This makes the writer interested in discussing it.

This study aims to describe the form of LUNTAS performance in the play Legend of Sawung Kampret, and to describe LUNTAS with its performance from the point of view of the performers and the audience of the show.

\section{METHODS}

This study used a qualitative descriptive method. Qualitative descriptive method is used to get a comprehensive picture of the subject matter, and analysis is carried out to bring up facts that can provide a deeper, comprehensive view of the problems to be discussed [3]. Based on this, the data collection techniques used are document studies and interviews. Bogan in Sugiono [4] states "in most traditions of qualitative research, the phrase personal document is used broadly to refer to any first person narrative produced by an individual which describes his or her own actions, experiences and beliefs".

This study examines the form of LUNTAS performance in the play Legenda Sawung Kampret, and LUNTAS with its performance from the perspective of the players and the audience of the show. The researcher reviews in detail what happened with the data obtained from members of the Ludruk LUNTAS group, namely the LUNTAS coordinator.

Data analysis is the process of arranging the sequence of data, organizing it into a pattern, category, and basic unit of description. The data that has been collected is processed, selected and classified based on their needs and then the data is compared with what has been obtained in the library. After finding the hypothesis, the data that has been obtained will look for the correct facts through mixing the two elements so that it becomes a fact that can be accounted for by the truth and also analyzed by means of interpretation, so that it becomes a form of synthesis which is a meaningful unit.

\section{RESULTS AND DISCUSSION}

Advised by Ahmadi et al., [5] Ludruk as the name of the phenomenon of performing arts in the East Java region etymologically comes from the word gelo-gelo which means shaking, and gedrag-gedrug which means stomping the foot so that it sounds drug. In reality, ludruk is a rhythmic movement and verbalization. Rhythmic movements are especially evident during the heroic dance (called remo) and storytelling, while verbalization is especially evident when pronouncing lyric poetry to the rhythm of East Javanese music from July to July (called kidung), comedy scenes, and story dialogues. As a traditional theater art, ludruk $(\mathrm{g})$ is a dramatization of folktales which is preceded or interspersed with the pronunciation of kidung as oral poetry. Thus, ludruk(g) is a folklore phenomenon.

LUNTAS is one of the groups that preserve youth ludruk from Surabaya. $\mathrm{He}$ is only five years old (established since 2016). One of the uniqueness of LUNTAS is the concept of LUNTAS which is closer to the Millennial generation, as well as the LUNTAS story which is more directed towards comedy with a combination of opera comedy, Japanese comedy, and so on that has not been found in other ludruk. LUNTAS has fifteen active members from various backgrounds, workers, students, students, the general public.

LUNTAS very seriously loves ludruk. This is proven, only LUNTAS is the only ludruk that has its own stage, not only one, but two stages which are located at Warung Mbah COKRO and another at Anak Jaya Bapak Sejahtera (AJBS) Surabaya, which was originally planned to be inaugurated in April 2020 but was delayed because of the pandemic Covid-19.

The LUNTAS practice schedule before the People's Amusement Park (THR) is evicted, is Tuesday and Thursday night. After being evicted, they were transferred to Warung Mbah COKRO every Sunday afternoon. Besides ludruk, LUNTAS also tries to create an open cultural space for all artists in Surabaya. "At Warung Mbah COKRO, all artists can use it for free, no proposals, local regulations and others are needed. It doesn't need to be complicated like when we work in government buildings." (Interview with Robert, 5 Mei:2020).

\subsection{LUNTAS Performance Form in the Legend of Sawung Kampret}

The structural element of ludruk is the component that builds the art form of ludruk. These components are remo dance; chant; comedy; bedhayan/panembromo; play story; Intermezzo. Of the six components, the component that is always present in every appearance of the variety of ludruk is the song and the story of the play. The complete variety of ludruk is characterized by the presence of all these components [5]

The structure of performances in ludruk since the beginning of independence until now has not changed. Basically the structure of ludruk performances is always followed from generation to generation in a traditional way. The opening begins with the Remo Dance which is a typical dance of East Java, After that it is continued by Bedhayan, which is the attraction of the artists swaying while singing. The next scene is a slapstick which is one of the episodes of the show's structure that brings a humorous scene. The last is the presentation of the play or story [2].

Traditional art in general has a characteristic that is always maintained as a conventional form that has been 
traditional and maintained by the actors of the culture concerned [6]. Traditional and Modern theater both require a serious process. In principle, these two theaters are still very likely to develop. Traditional art has interesting forms and concepts that make the audience feel impressed when watching performances presented by traditional arts groups.

In the form of performances displayed by LUNTAS in several performances, especially in the play Legend of Sawung Kampret, it underwent several modifications for several reasons. Some forms of performance that are generally often performed by LUNTAS in this case the play Legend of Sawung Kampret are as follows:

\subsubsection{Remo}

Dance Remo dance is a dance form that comes from the art Ludruk. Ludruk is a typical traditional art originating from East Java, Ludruk can also be said as folk theater. The word Ludruk comes from the word gedruk which has a characteristic in art that always performs gedruk movements in every dance, so it is called Ludruk [7].

Remo dance is one of the dances for welcoming guests that is performed by one or more people (see Figure 1). This dance comes from East Java Province. The most important characteristic of the Remo Dance is the dynamic and fluid movement of the feet. This movement is supported by the presence of gongseng, namely bells that are mounted on the ankles. This gongseng sounds when the dancer steps or stomps on the stage. In addition, other characteristics, namely the movement of the shawl or sampur, the movement of nodding and shaking of the head, facial expressions, and the horses of the dancers make this dance more attractive.

The remo dance in the LUNTAS play Legend of Sawung Kampret is a type of Remo Bolet. This dance is performed singly. "In the meantime, we only have a Remo dancer, Bolet is more passionate," said Robert Bayoned. The origin of Remo Bolet is the city of Jombang. The recognition of this type of Remo dance comes from the strains of the gamelan music. This dance was originally a dance that was used as an introduction to the performance or the opening of ludruk. The hallmark of the Remo Bolet dance is the agile movement of the feet plus the pounding of the feet together.

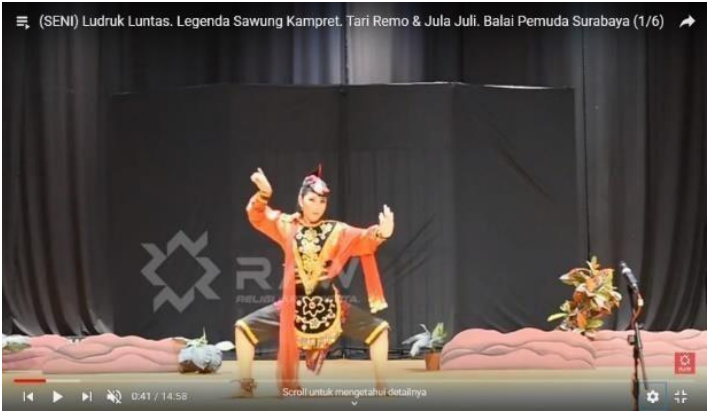

Figure 1 Remo Dance Scene.

https://www.youtube.com/watch? $v=$ mi2jVS7wtRI

\subsubsection{Bedhayan}

Bedhayan is a light dance performed by several travesti while chanting kidungan jula-juli (see Figure 2). In the LUNTAS performance of the Legend of Sawung Kampret, it was said by the Ludruk coordinator who played the slapstick that the Bedayan was deliberately skipped. It says in it that "ora opo-opo, it's not good to be different. Bedayan is sunnah ning ludruk, if you feel good, it's good, or not, it's okay. Completely, I don't want to follow the standard, zinc is important, isone arek-arek yoopo, namely zinc on the stage. Zinc is important when it comes to ludruk, this is still being preserved, mergo zinc is needed or not just to preserve the pitcher of ludruk players, but let's preserve the audience of ludruk". Which means, it's okay if there's no bedhayan. Because bedhayan law is sunnah in ludruk. If it's there it's fine, if it's not it's fine. This PASS does not really follow the standard. How there are friends, that's what is staged. The important thing is that this ludruk art can be preserved. Because what is needed is not only the preservation of the ludruk players, but also from the audience.

Based on the interview conducted by the researcher to the LUNTAS Coordinator, it was said that, "The adadua standard, the Ludruk structure principle and the story principle. In ludruk many are used by ludruk artists themselves. Whereas what we observe is creativity to make ludruk look better. The rules of ludruk itself have Remo, Jula Juli (jokes) and stories. The others, according to us, are not standard, but because of the conditions at the time and the creativity of the ludruk artists."

But actually, there was a travesti that appeared the first time that danced with free and relaxed movements. This travesti briefly danced alone, which was then followed by a slapstick figure. The two of them continued the joke. "LUNTAS still uses Bedayaan, but because at Balai Pemuda we are limited in duration, sometimes we use it sometimes not. The sunnah means that Bedhayan is a choir to just sweeten the performance, or it could be to prolong the duration for the preparation of the ludruk play players." he added.

In research, the form of bedhayan in LUNTAS itself adjusts to the availability of Human Resources. 


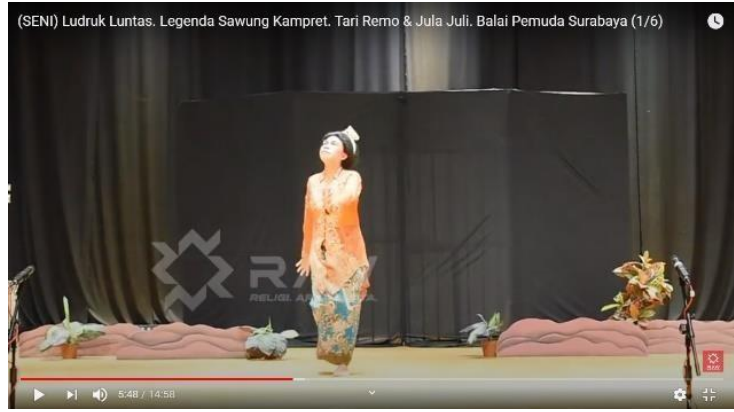

Figure 2 Bedhayan by a travesty who doubles as a slapstick https://www.youtube.com/watch?v=mi2jVS7wtRI

\subsubsection{Dagelan (Slapstick)}

Slapstick is a dialogue scene with humor material (see Figure 3). Dagelan in the ludruk play Legenda Sawung Kampret, played by two people, namely the ludruk coordinator named Robert and a travesty who later changed into a male costume, named Ipul.

The slapstick begins with the July-July chant sung by Robert. In the song, it discusses the struggle of the people of Surabaya in fighting for independence. This song uses two types of tones, the first is the kidungan type of lamba and the second is the song dangdut accompanied by gamelan.

Then Ipul appeared accompanying Robert. In this slapstick, both of them are very good at improv. The author said that the jokes they brought were funny and very entertaining. This is one of the characteristics of the LUNTAS slapstick form, namely the comedy is very funny and close to the problems of the community. It is evidenced by the response of the audience's laughter that breaks out every time the character delivers a comedy dialogue.

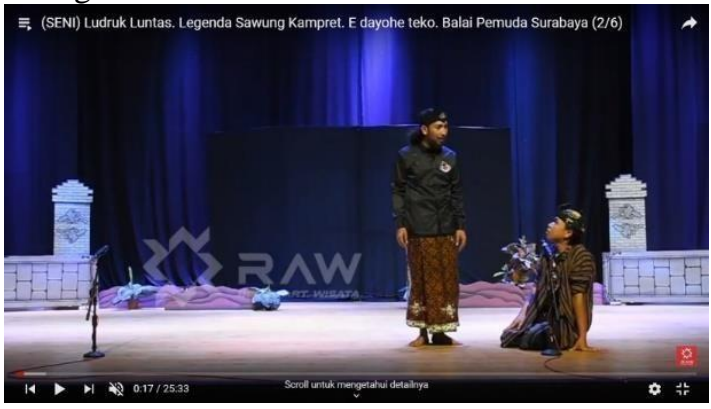

Figure 3 Slapstick by Robert and Ipul. https://www.youtube.com/watch?v=HJTxx_h8MP8

This slapstick contains discussions about religion, social, morals, and the latest issues in people's lives.

\subsubsection{Act}

Drama plays have dramaturgical aspects that support narrative events in them. According to Aristotle (in [8], the aspects of dramaturgy are divided into plot, theme, characterization, speech style, sound effects, spectacle, and convention. From these aspects, dramaturgical aspects are specified into the structure and texture of drama. The structure of the drama consists of plot, theme and characterization. Drama texture consists of dialogue, spectacle and mood. The examples of drama stage can be seen in Figure 4. The existence of the structure and texture of the drama complement each other in building the integrity of the information to be conveyed.

In this study, the specs that will be the main focus are the characterizations, plot, themes, dialogues, spectacle (spectacle), and mood (feelings). The six elements observed in the video staging the Legend of Sawung Kampret.

\subsubsection{Drama Structure}

Kernodle in [9] divides the elements that create the structure of the drama into three, namely theme, plot, and character.

Cohen [8] defines theme as a statement of the whole drama: its topic,idea main, or message, depending on the circumstances. The theme for staging the Legend of Sawung Kampret is struggle. This story describes Sawung Kampret's struggle against the Dutch colonists who did injustice to the natives.

Cohen [8] describes that the dramatic experience according to Aristotle in the plot is at least divided into four; exposition (introduction) (see Figure 4), conflict (problem) (see Figure 5), climax (climax) (see Figure 6), denouement (solution) (see Figure 7). The plot in the Legend of Sawung Kampret is a type of linear plot, where the story is told coherently from beginning to end. There are four stages of plot in this play, namely introduction, problem, climax, and completion. The dramatic ladder in this play is clearly visible.

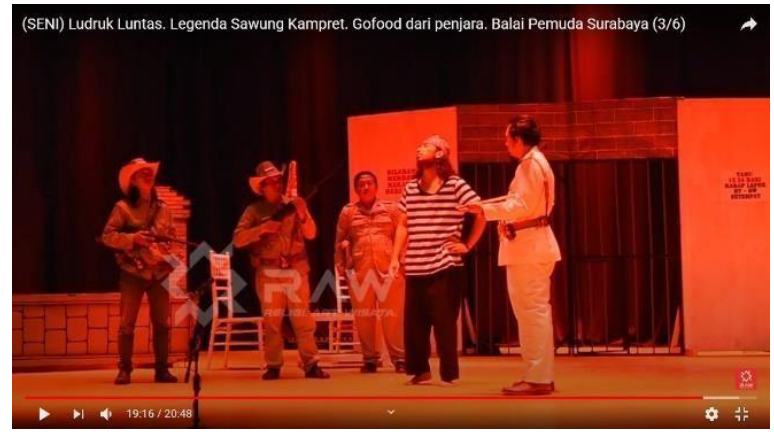

Figure 4 Initial Scene Introduction Stage. https://www.youtube.com/watch?v=RAax4qSaVFg

The introduction stage was built with a comedy between Robert who played Sumolewo and Ipul as Maruto. In this introduction stage, the atmosphere 
displayed is a fluid atmosphere, by incorporating the latest issues in people's lives. For example, by involving Go Food courier figures. After that the story is built seriously.

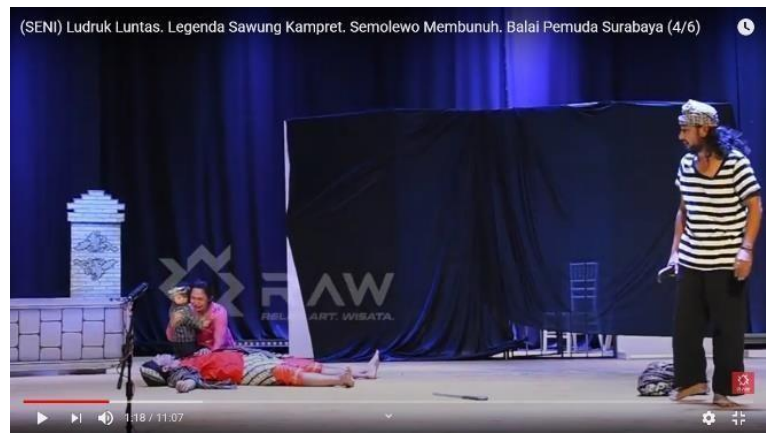

Figure 5 The Problem Stage Scene. https://www.youtube.com/watch?v=AUpoRJHnHb8

The problem stage in this play is presented in a serious style, but does not release the comedy element.
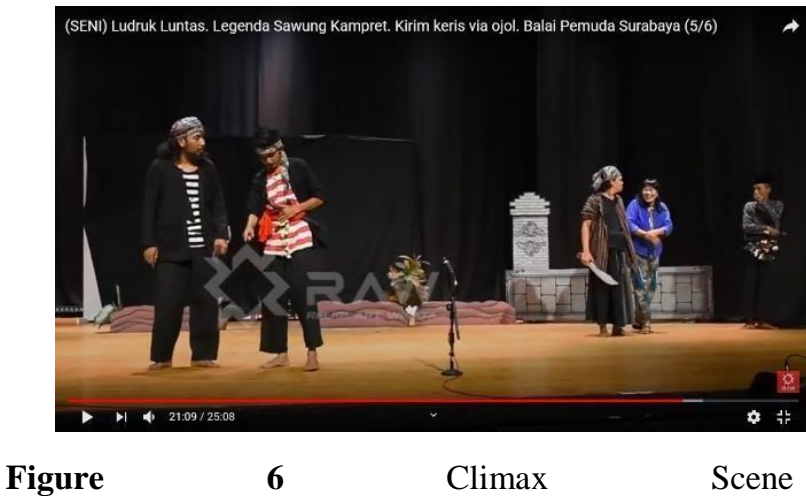
https://www.youtube.com/watch?v=21_jV_pSsTM

In the climax scene, the entire character unit plays its character to the fullest. Comedy began to be reduced. The appearance and style of the actor's play is increasingly visible.

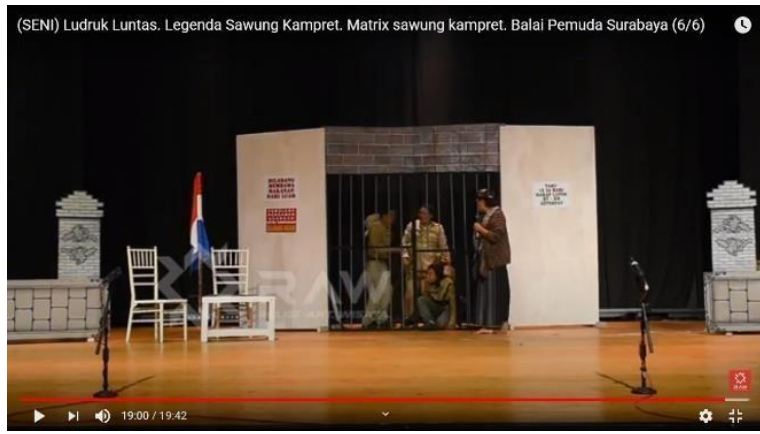

$\begin{array}{lllll}\text { Figure } & 7 & \text { The } & \text { Settlement } & \text { Scene. }\end{array}$ https://www.youtube.com/watch?v=tY-pRuMUJ_s

Finalis the completion stage. The atmosphere created in the ending scene by the characters is maximized. In the stage leading to the ending, each character focuses on the course of the story. But at the end of the ending scene added comedy. After that all the characters involved appeared on the stage to give a closing salute.
Characters are plot actors who interact with each other through problems in the events that are built [8]. In the process of its creation, LUNTAS is open to anyone who wants to join in preserving LUNTAS art. "We have never held a recruitment, starting from 6 close friends and my theatre students. Members who join are usually members who are interested after seeing the activities completed. LUNTAS never had any casting, everyone learned to play directly on stage, everything was arranged by the director and the creative team. Everyone learns from the habits on stage." (Interview with Robert, 5 May:2020). The characterizations in this play as a whole are good, but there are some characters whose characters are still not visible.

(1) Sumolewo, Sumolewo has an antagonistic character. A traitor for being a dutch minion and killing the person who saved him. The character and style of the game is good.

(2) Maruto, Maruto has a deuteragonist disposition. Side with the protagonist. Supports groove movement. Kind, help Sawung solve the problem. The characters that are presented are good, the style of play often brings up comedy.

(3) Groats, Groats have an antagonistic disposition. Motivator of the plot of Dutch crime. The characters that are presented are not optimal. Actor is still hesitant to play a role.

(4) Sawung Kampret, Sawung Kampret has the character of a protagonist. Courageous. Able to defend the nation with his struggle. The cast of Sawung Kampret is a teenage boy, Robert's biological son. His style of play is still uncertain. However, in character, he has tried his best.

(5) Dutch Captain and Soldier Foil. This character sided with the antagonist. Stupid and easily fooled character. His appearance looks dashing, but the style displayed is comedy.

(6) Natives (friends sawung, prisoners, wives, mothers, and girls) have a utility character. A supporting character who sided with Sawung. From some of the natives, in general, the characters are almost maximal, I just don't think the style of the game and the dialogue are sure yet. There are also indigenous characters who play in a unique, funny, and interesting style. Namely the wife of Sawung Kampret's friend. His character is strong when he plays a coquettish character, the comedy that is conveyed can also be captured humorously.

\subsubsection{Texture}

Kernodle [10] defines the texture of drama as a direct experience that is present through the senses, something heard (dialogue), something seen (spectacle) and something felt through visual and aural experience (mood/atmosphere). 
In dialogue there is a style of speech [8] describes diction (speech style) not only covering how to pronounce dialogue but more oriented to how characters are built based on the orientation of the script. The dialogue used in Ludruk LUNTAS is a verbal dialogue that uses the everyday language of the people of Surabaya. The dialogue between the characters has a good reciprocal response, although at times there are overlapping dialogues between actors. The delivery of dialogue can be well received by the audience.

Cohen [8] describes Spectacle (spectacle) as the visual aspects of the stage that need to be presented to add to the dramatic element of a show. Spectacles are raised a lot when jokes. Spectacles are raised through dialogue between characters and actions of characters. There are no spectacles artistic that are raised. It's just that, through his jokes and his actions, the audience is amazed and can't understand what is shown. The costumes and make-up used are costumes colonial and indigenous that are in accordance with the theme of the story. The lighting arrangement uses general types and colors that support the atmosphere. The acting business of each character has a diverse acting business. There are characters who have a strong acting business, but some are still weak or doubtful. The stage room consists of a prison setting at the beginning of the show consisting of a prison and a fence on the right and left of the stage, then it turns into a village setting by covering the prison setting with a black backdrop cloth. Settings are intact at the beginning. Changing settings just open and close settings that are not needed.

Kernodle [10] defines something that is felt through visual and aural experiences (mood/atmosphere). The atmosphere formed in LUNTAS is comedy, tense, sad, and tragic. The play in LUNTAS brings up more comedy in each plot of the script, so that the audience doesn't get bored. But the negative, the atmosphere formed between actors in terms of taste and appreciation is very lacking. In supporting the atmosphere, there is music. Cohen [10] describes music (sound effects) more referring to the production of sounds that can describe the atmosphere in supporting the performance. The music used to support the atmosphere in the Legend of Sawung Kampret is gamelan music as the main instrument, bringing up atmosphere music, background music, and effects music.

\subsection{LUNTAS with the form of the show from the point of view of the performer and the audience of the show}

LUNTAS's point of view with the form of the performance from the side of the players and the audience in terms of characteristics, uniqueness, and function. One of the characteristics and uniqueness of LUNTAS is its fluidity in comedy. LUNTAS story which is more directed to comedy with a combination of opera comedy, Japanese comedy, and so on that has not been found in other ludruk and. "Game jokes are never playful in their work," explained Robert. LUNTAS has members from various backgrounds, workers, students, students, the general public. In addition, it has a concept that is close to the Millennial generation.

The main function of LUNTAS is as a media for public entertainment. In addition, LUNTAS also functions as a disclosure of the atmosphere of community life. In addition, this art is also often used as a channel for social criticism of the government situation and also the problems that occur in society. In addition, LUNTAS serves as a forum to introduce the art of ludruk in the most interesting way for Surabaya youth. The goal is that more and more Surabaya teenagers are familiar with the art of ludruk with all the moral messages contained in it through LUNTAS. "Luntas not only regenerates ludruk players, but also seeks a generation of ludruk viewers. It's useless we have a generation of players, but no one is watching. It's our homework that brings ludruk closer to the current generation so that it doesn't disappear." said Robert.

\section{CONCLUSION}

The form of LUNTAS performance is not tied to the structure of ludruk performances in general, because LUNTAS seeks to adapt to the community environment by maximizing the capabilities of existing human resources. In his belief, the LUNTAS performance is performed solely to preserve the art of ludruk both from the presenter and from the audience, so that in the end LUNTAS can be well received by all levels of society.

LUNTAS's point of view with the form of the performance from the side of the players and the audience in terms of characteristics, uniqueness, and function. LUNTAS as a medium of public entertainment and also as a disclosure of the atmosphere of people's lives, through the millennial ludruk concept, LUNTAS wants to bring ludruk closer to the millennial generation by emphasizing comedy stories in which it contains useful moral messages.

\section{AUTHOR'S CONTRIBUTION}

Through this paper, it is hoped that it will be able to provide insight for the public, especially the millennial generation, to continue to love and preserve traditional arts, in this case ludruk, both as players and as spectators. LUNTAS can be used as an interesting spectacle for ordinary people to enjoy or learn the traditional art of ludruk.

Traditional theater must be able to adapt to the times so that it can show itself in all ages. Therefore, awareness is needed in cultivating enthusiasm in appreciation and participation to take part in the preservation of traditional arts. 


\section{ACKNOWLEDGMENTS}

Praise the presence of Allah SWT who has bestowed His mercy and grace so that this article can be completed smoothly. This article would not have reached the completion stage without the help of various parties. With all humility, the author expresses his gratitude to all those who have helped the smooth writing of this article.

Although it is far from perfect, due to limited thoughts and knowledge and in the context of pioneering insight and experience, it is one of the reasons that in writing this article there are still many shortcomings. Therefore, constructive criticism and suggestions are always expected for the sake of making this article better.

\section{REFERENCES}

[1] F. Fatoni, "Ludruk's Directing Technique with "Nyi Cindhe Amoh" Script by Cak Edi by Director Ahmad Fatoni," Solah Journal, vol. 6, no. 2, 2016.

[2] K. Kasemin, Ludruk as Social Theater. Surabaya: Airlangga University Press, 1999.

[3] E. Sedyawati, "Cultural Awareness in Education, Information, and Industry," National Seminar on Cultural Awareness Strengthening the Nation, Jakarta, January, 2004.

[4] S. Sugiyono, Quantitative, Qualitative, Research Methods and R\&D. Bandung: PT Alphabet, 2016.

[5] M. Ahmadi, et al., Aspects of Literature in the Art of Ludruk in East Java. Head of Language Center Library, 1987.

[6] A. Widayat, "Ketoprak Seni Pertunjukan dan Seni Sastranya, Media Menuju Konteks, Multikultural". In Seminar Nasional Pemberdayaan KBJ III di UNY Yogyakarta, 2001.

[7] H. Lisbijanto, Ludruk, Yogyakarta: Graha Ilmu, 2013.

[8] R. Cohen, Theater (9ed). New York: McGraw-Hill Companies, Inc, 2010.

[9] C.Dewojati, Drama: sejarah, teori, dan penerapannya. Gadjah Mada University Press, 2010.

[10] G.R. Kernodle, George R. (1967). Invitation to Theatre, New York: Hancourt, Brace \& World, Inc, 1967. 